\title{
THE EFFECTS OF THE WEALTH TAXES ON INCOME DISTRIBUTION IN TURKEY
}

\author{
Hülya KABAKÇI KARADENIZ ${ }^{1}$
}

\begin{abstract}
Ensuring fair distribution of income among individuals is one of the primary objectives of public fiscal policy in every country. Taxes have an impact on the second income distribution. In particular, increasing rates of direct taxes have a positive effect on income redistribution. The more fair a tax structure in a country, the more will be tax justice. One of the direct taxes is wealth taxes. The share of national income and wealth tax in Turkey is around four per thousand by the year 2017. The aim of the study is to examine the effect of tax on property tax on personal income distribution. In this study, the TURKSTAT Income and Living Condition Micro-Data Set (2017) was used. In case households do not pay motor vehicles tax and real estate tax, the median income per capita among the richest and poorest income groups is estimated 9,18 times. In case of payment of these taxes, it is decreased to 9,15 times. It implies property taxes have a limited effect on income redistribution. The reasons for the limited impact on the redistribution of income of wealth taxes in Turkey, the value of the real estates such as building, do not to reflect the real value of, low tax collection rates, tax exemptions, exemptions can be.
\end{abstract}

Keywords: Income Distribution, Tax justice, Wealth Taxes, Property tax, Motor Vehicle Tax.

JEL Code: K11, K34, H21

\section{Introduction}

Tax policies are of great importance in the provision of justice in income distribution. The government draws a portion of the resources in proportion to the incomes, expenditures and wealth of the economy through the tax mechanism. In addition, the state withdraws values from the economy through tax, and transfers through the public spending to the economy. Undoubtedly, distribution policies have a great importance in fair distribution of income. In the study, wealth taxes are examined as property tax and motor vehicle tax. Inheritance tax on the transfer of wealth were excluded from the study.

\section{The Relation of Taxes on Wealth and Distribution of Personal Income}

Income distribution types are personal income distribution, functional income distribution, sectoral income distribution and regional income distribution.Personal income distribution; shows how national income is shared among people who make up the population. In this study, the effects of personal income distribution and wealth taxes on this distribution will be examined. There is a close relationship between income inequality and per capita income. Income inequality cannot be completely eliminated. Therefore, it is accepted that thesecondary income distribution resulting from the intervention of the state is more equitable than the primary distribution (Erkul and Erkul, 2019: 19). The power to pay taxes undoubtedlyshows income, spending andwealth.

\footnotetext{
1 Assoc. Prof. Dr. Pamukkale University, hulyak@pau.edu.tr
} 
Therefore, tax policies aim to provide income (for income-generating purposes) as well as income distribution (Karabulut and Şeker, 2018: 1053). For a more equitable distribution of income; It is important to pay taxes, abilityto pay power (Demir, 1018: 47).

Wealth consists of the accumulation of revenue and is a static concept that refers to the stock status in relation to its assets. Inequality in income distribution in emerging economies is also high in the distribution of wealth. In most cases the level of wealth inequality of countries is twice as high as the income level (Murphy, R., Moreno-Dodson, B., and Zolt, E. M. 2017: 2). However, the tax policies implemented by countries have an effect of alleviating inequality in the distribution of wealth (Türk, 2007: 322). The rates of wealth taxes, which are the normal and permanent income source in terms of budget, and the tax burden on taxpayers remains low in Turkey (Öncel, Kumrulu and Çağan, 2008: 325). Some authors claims that wealth is not taxed exactly and there are some efforts on the wealthlike taxation in Turkey (Erol, 2012: 377).

Income and expenditure taxes are applied in order to realize the fiscal function. Wealth taxes are applied in order to realize social goals An important purpose of wealth taxes is to provide justice and equality in taxation and thus justice in income distribution (Ömür and Gerçek, 2017: 197). The tax system has a great effect on reducing inequalities in income and wealth distribution. The effect of taxes on the society is changing according to the indirect tax and direct taxes. In the case of a country's tax structure weighted by indirect taxes, it is widely estimated that tax burden affects people with lower income levels. On the contrary, in a tax system where direct taxes are predominant, the tax burden increases in people with high income levels (Akdoğan, 2017: 499). As the income tax rate has an increase, the lower income groups pay less tax, and the higincome groups pay more tax. Therefore, post-tax income is expected to improve in favor of persons in the low-income group (Pınar, 2015: 297). Indirect taxes do not take consider of tax pay power. In other words, , consumers who have high consumption trends and low income levels pay high taxes, more than high income groupscompare with their income In order to overcome this injustice, the share of direct taxes in tax revenues should be increased (Eğilmez, 2016: 66). In the Turkish tax system, inheritance tax, which is one of the wealth taxes and it is classifed in the direct taxes. Inheritance tax is called "there is tax name. But it does not exist itself" (Bilici, 2013: 183). It is the motor vehicle tax that has the largest share among the total tax revenues within the wealth tax system. The value of the vehicle in taxation, as well as cylinder volumes, number of seats, are take considered. The property tax, which is another wealth tax, is the second largest wealth tax that has an important share in wealth tax revenues. (Şener, 2007: 219). In Turkey, the share of total tax revenue of the estate tax is relatively low compared to EU countries. On the contrary, the share of motor vehicle tax in total tax revenues is high (Ömür ve Gerçek, 2017: 197). In 2018, the share of motor vehicle tax in total tax revenues was $2 \%$ in GDP $(0,33 \%)$ (muhesebat.gov.tr). In 2017, the share of real estate tax in total tax revenues was $0.9 \%$ and the share in GDP was $0.2 \%$ (OECD, 2019). The value of automobile has been taken considered while motor vehicle tax amount has been calculated, since 2018. It can be said that the new system is more fair (Kabakçı Karadeniz, 2018). Therefore, the share of motor vehicle tax in tax revenues may be expected to increase in the following years. 


\section{The Impact of The Wealth Taxes on Personal Income Distribution in Turkey}

\subsection{Data Set and Method}

In order to determine the effect of wealth taxes on income distribution, the micro data set of 2017 was used. The micro data set includes motor vehicles tax and property tax, which households regularly pay. The per capita income is ranked from low to high and the households are divided into 10 equal groups. In the case of the payment and non-payment of the tax, the income gap between the richest 10th income group and the poorest 1st income group was compared in 10 income groups.

\subsection{Findings of the Study}

The difference between the income group and the poorest income group is 9,18 if the wealth taxes do not impose. In the case of the payment of these wealth taxes, the difference decrease to 9.15 .

Table 1: Wealth Tax in Turkey (Real Estate Tax and Motor Vehicle Tax), Per Capita by Income Group (2017)

\begin{tabular}{|l|l|l|}
\hline & & $\begin{array}{l}\text { In the event of not paying the wealth tax, } \\
\text { Per capita income (TL) }\end{array}$ \\
\hline 1 (Poorest) & Per Person Income Tax Paid (TL) & 5940 \\
\hline 2 & 5625 & 8774 \\
\hline 3 & 8336 & 11047 \\
\hline 4 & 10523 & 13103 \\
\hline 5 & 12573 & 15463 \\
\hline 6 & 14684 & 18039 \\
\hline 7 & 17224 & 21359 \\
\hline 8 & 20252 & 25745 \\
\hline 9 & 24557 & 33479 \\
\hline 10 (Richest) & 31800 & 54540 \\
\hline $\begin{array}{l}\text { The Richest Groups' Income/ } \\
\text { Poorest Income Group }\end{array}$ & 9,15 & 9,18 \\
\hline
\end{tabular}

Source: TURKSTAT, Income and Living Conditions Survey were calculated by the author from the 2017 Micro Data Set.

*1 refers to the poorest income group and 10 to the richest income group.

It can be said that wealth taxes in Turkey almost have no redistribution effect. The low share of these taxes in GDP may be an indication that wealth is not taxed enough. 


\section{Conclusion}

The wealth taxes in GDP is low in Turkey. There may be many reasons why this share is low in Gdp. These include motor vehicle tax and real estate tax exemption and exemptions, low collection rates. Frequent tax amnesties can be reduced tax collection rates. In addition, the taxation value of propertyare usuaaly belowthe real value of real estate. It causes decrreasing wealth taxes. In this study It is found that real estate tax and motor vehicle tax had a very limited corrective effect on the redistribution of income, in favor of the low income groups. The suggestions for providing corrective effects on income redistribution in wealth taxes are presented below.

a)The methods need to be developed to determine the real value of wealth (especially real estate), which is the basis for the calculation of the tax. It is a positive development to consider the values of automobiles in the taxation of motor vehicles with the arrangement made in motor vehicles tax in 2018 (Kabakçı Karadeniz, 2018).

b) Exemptions and exemptions in real estate tax and motor vehicles tax should be reviewed and reduced (Kabakçı Karadeniz, 2016).

c) New security measures should be developed to increase the tax collection rate.

\section{References}

Akdoğan, A. (2017). Kamu Maliyesi, 18. Baskı, Ankara, Gazi Kitabevi.

Bilici, N. (2018). Türk Vergi Sistemi, 42. Baskı, Ankara, Savaş Yayınevi.

Demir, İ. C. (2018). "Türk Vergi Sisteminin Klasik Vergileme Illkeleri Bakımından Analizi”, In 6 SCF International Conference on Economic and Social Impacts of Globalization and Liberalization, October, p. 46.

Eğilmez, M. (2016). Kamu Maliyesi, 4. Baskı, İstanbul, Remzi Kitabevi.

Erkul, E. \& Demir-Erkul, F. (2019). “Neoliberal Politika Çerçevesinde Türkiye ve Şili'ye Illişkin Gelir Dağılımı ve Yoksulluk İstatistiklerinin İncelenmesi”, Sosyoekonomi, p. 27.

Erol, A. (2012). Türk Vergi Sistemi ve Vergi Hukuku, 3. Baskı, Ankara, Yaklaşım Yayıncılık.

Kabakçı Karadeniz. (2018). “Otomobiller Üzerinden Alınan Motorlu Taşıtlar Vergisinin Vergi Adaleti Açısından Incelenmesi", International Journal of Public Finance, Cilt: 3, Sayı: 2, ss. 193-204.

Kabakçı Karadeniz. (2016). "Türk Emlak Vergisinin Vergi Adaleti Açısından Değerlendirilmesi", Legal iş Hukuku ve Sosyal Güvenlik Hukuku Dergisi, Jan., pp. 0-0.

Karabulut, R. \& Şeker, K. (2018). “Belirlenmiş Değişkenlerin Vergi Gelirleri Üzerindeki Etkisi: Çoklu Doğrusal Regresyon Analizi", Suleyman Demirel University Journal Of Faculty Of Economics \& Administrative Sciences, 23(3).

Murphy, R., Moreno-Dodson, B. \& Zolt, E. M. (2017). Wealth Taxes in Developing Countries.

Ömür, Ö. M., Gerçek, A. (2017). "Türkiye ve Avrupa Birliği Üyesi Ülkelerde Servet Vergilerinin Karşılaştırılması", MCBÜ Sosyal Bilimler Dergisi, Cilt: 15, Sayı: 2, Haziran, İktisadi ve İdari Bilimler Sayısı. 
Öncel, M., Kumrulu, A. \& Çağan, N. (2008). Vergi Hukuku, 15. Bası, Ankara, Turhan Kitabevi.

Pınar, A. (2015). Maliye Politikası, 8. Baskı, Ankara, Turhan Kitabevi.

Şener, O. (2008). Kamu Ekonomisi, 10. Baskı, İstanbul, Beta Basım Yayın Dağıtım.

Türk, ì. (2007). Maliye Politikası, 20. Bası, Ankara, Turhan Kitabevi.

OECD. Stat. (2019). https://stats.oecd.org/viewhtml.aspx?datasetcode=REV\&lang=en\#, (26.02.2019).

www.muhasebat.gov.tr, (26.02.2019). 